\title{
ANALISIS POTENSI LIKUIFAKSI DI KELURAHAN LEMPUING KOTA BENGKULU MENGGUNAKAN PERCEPATAN MAKSIMUM KRITIS
}

\author{
Lindung Zalbuin Mase ${ }^{1}$, Andri Krisnandi Somantri \\ ${ }^{1}$ Staf Pengajar Jurusan Teknik Sipil, Fakultas Teknik,Universitas Bengkulu, Jl. W.R. Supratman, \\ Kandang Limun, Bengkulu 3837, Email: lindungmase@yahoo.co.id \\ ${ }^{2}$ Staf pengajar Jurusan Teknik Sipil, Politeknik Negeri Bandung, Jl. Gegerkalong Hilir Ds.Ciwaruga \\ Bandung 40012. Email: krisnandi16@gmail.com.
}

\begin{abstract}
ABSTRAK
Pada tanggal 12 September 2007, gempa dahsyat berkekuatan 7,9 SR, mengguncang Propinsi Bengkulu. Kejadian gempa tersebut menyebabkan kerugian yang besar, di antaranya runtuhnya bangunan rumah tinggal penduduk dan gedung, rusaknya sarana-prasarana infrastuktur, hingga terjadinya beberapa bencana ikutan lainnya, seperti longsoran dan likuifaksi. Fenomena likuifaksi akibat gempa tersebut, ditemui hampir secara massif di kawasan pesisir Provinsi Bengkulu. Salah satu daerah yang terkena dampak likuifaksi adalah Kelurahan Lempuing, yang letaknya di pesisir pantai barat sumatera. Belajar dari pengalaman di tahun 2007, sebuah studi mengenai potensi likuifaksi berdasarkan data penyelidikan tanah di Kelurahan Lempuing dirancang untuk dilakukan. Penelitian ini bertujuan untuk mengetahui potensi likuifaksi berdasarkan percepatan maksimum kritis yang menjadi syarat minimal percepatan maksimum gempa (peak ground acceleration (PGA)), yang memicu potensi likuifaksi dalam keadaan kritis atau yang memiliki faktor aman $(F S)$ bernilai 1. Hasil analisis menunjukkan bahwa akibat PGA kritis rata-rata, nilai faktor aman yang dihasilkan berkisar antara 0,503 dan 2,64. Hasil analisis juga menunjukkan bahwa secara umum, likuifaksi berpotensi terjadi pada kedalaman 0 sampai 6 meter, meskipun pada titik penyelidikan tertentu likuifaksi juga berpotensi terjadi pada kedalaman 7,5 sampai 8,5 meter. Analisis probabilitas likuifaksi menunjukkan bahwa semakin besar faktor aman, maka probabilitas likuifaksi menjadi semakin kecil. Hasilanalisis ini juga menunjukkan bahwa probabilitas kritis untuk $F S=1$, bernilai 0,54 (54\%).
\end{abstract}

Kata kunci:likuifaksi, lempuing, PGA kritis

\section{Pendahuluan}

Provinsi Bengkulu merupakan salah satu wilayah di Indonesia yang rentan terhadap bencana alam gempa bumi.Dalam 1 dekade terakhir, tercatat dua buah gempa dahsyat melanda Provinsi Bengkulu. Kedua gempa tersebut adalah gempa tektonik dengan kekuatan 7,3 SR (Skala Richter) yang terjadi pada tanggal 4 Juni 2000, dan gempa tektonik berkekuatan 7,9 SR yang terjadi pada tanggal 12 September 2007. Kedua kejadian gempa tersebut telah menimbulkan begitu banyak kerugian material maupun jiwa, serta bencana yang mengikuti kejadian gempa-gempa tersebut, seperti likuifaksi.

Gempa yang terjadi di Provinsi Bengkulu pada tanggal 12 September 2007 silam menjadi salah satu gempa terbesar yang pernah terjadi. Gempa tersebut tidak hanya menimbulkan kerusakan bangunan dan sarana prasarana, tetapi juga memicu kejadian likuifaksi yang cukup masif. Kejadian likuifaksi berupa semburan pasir dan sebaran lateral terjadi hampir merata di kawasan pesisir pantai Provinsi Bengkulu. Salah satu area yang mengalami kejadian likuifaksi di wilayah Bengkulu, adalah Kelurahan Lempuing, yang langsung berbatasan dengan pantai barat sumatera. Belajar dari pengalaman gempa dahsyat di masa lalu, penelitian-penelitian mengenai potensi likuifaksi khususnya di kawasan pesisir pantai Provinsi Bengkulu mulai dilakukan secara intensif.

Beberapa penelitian likuifaksi di Kawasan Lempuing telah dilakukan sebelumnya oleh beberapa peneliti, di antaranya Misliniyati dkk. (2013) dan Monalisa dkk. (2014). Misliniyati dkk. (2013) melakukan studi mengenai potensi likuifaksi di Kelurahan Lempuing berdasarkan data CPT (Cone Penetration Test) atau sondir, menggunakan metode yang diusulkan oleh Idriss dan Boulanger (2008). Dalam penelitian

PUEnSI Anaisis Potensi Likuifaksi di Kelurahan Lempuing Kota Bengkulu Menggunakan Percepatan Maksimum Kritis 45 Lindung Zalbuin Mase dan Andri Krisnandi Somatri 
mereka, nilai percepatan maksimum gempa yang digunakan dalam analisis adalah sebesar $0,4 \mathrm{~g}$ yang mengacu pada pada peta gempa 2010 (SNI 03-1726-2010). Pengambilan nilai 0,4g sebagai parameter percepatan maksimum, disebakan karena tidak tersedianya percepatan maksimum gempa akibat gempa 2007 silam. Dalam penelitian mereka, disimpulkan bahwa likuifaksi berpotensi terjadi di Kelurahan Lempuing pada kedalaman yang cukup dangkal.

Monalisa dkk. (2014) melakukan studi probabilitas likuifaksi di area penelitian yang sama dengan Misliniyati (2014). Dalam penelitian tersebut, Monalisa dkk. menggunakan data dan parameter percepatan gempa yang sama dengan Misliniyati dkk. (2014). Dalam penelitiannya, Monalisa dkk. (2014) menggunakan model probabilistik yang diusulkan oleh Haldar dan Tang (1979) untuk menentukan probabilitas likuifaksi pada wilayah penelitian mereka. Berdasarkan hasil penelitian mereka, potensi likuifaksi akan semakin besar terjaadi seiring dengan meningkatnya probabilitas likuifaksi itu sendiri. Hasil analisis yang dilakukan oleh Monalisa dkk. (2014) memperkuat dugaan bahwa likuifaksi berpotensi terjadi dengan skenario percepatan gempa yang tertera pada SNI 031726-2010.

Mengacu pada penelitian terdahulu, terlihat bahwa percepatan maksimum yang digunakan dalam analisis adalah percepatan gempa yang diperoleh dari peraturan gempa untuk wilayah Indonesia. Hal ini dilakukan karena rekaman percepatan gempa maksimum akibat gempa 2007 bersifat terbatas atau tidak tersedia. Sebagai solusi untuk mengatasi hal tersebut, maka dilakukanlah analisis potensi likuifaksi dengan menggunakan konsep keadaan kritis. Keadaan kritis yang dimaksud adalah keadaan dimana faktor aman $(F S)$ likuifaksi berada pada ambang batas likuifaksi tidak terjadi, atau dapat dinyatakan sebagai $F S$ bernilai 1 .

Muntohar (2009) melakukan penelitian mengenai evaluasi PGA menggunakan data CPT untuk analisis potensi likuifaksi. Area penelitian yang diteliti oleh Muntohar (2009) adalah Kampus UMY yang pada 2006 silam mengalami beberapa kejadian likuifaksi akibat gempa berkekuatan 5,9 SR. Dalam penelitannya, Muntohar menganalisis batas minimal PGA yang diperlukan untuk memicu terjadinya likuifaksi di lokasi tersebut. Berdasarkan hasil penelitiannya, rentang PGA minimum yang mampu memicu terjadinya likuifaksi di wilayah tersebut adalah sebesar $0,36 \mathrm{~g}$ sampai dengan $0,68 \mathrm{~g}$. Nilai rentang PGA tersebut berpotensi memicu terjadinya likuifaksi dengan kedalaman lebih dari 50\% dari total lapisan yang ditinjau.

Muntohar (2014) melakukan penelitian mengenai gempa yang menyebabkan likuifaksi di Kota Padang dan Area Yogyakarta. Dalam analisisnya, estimasi percepatana minimal yang mampu menyebabkan likuifaksi di Kota Padang adalah sebesar $0,14 \mathrm{~g}$ dan $0,48 \mathrm{~g}$ untuk Area Yogyakarta. Muntohar (2014) juga menyebutkan bahwa perhitungan analisis balik menggunakan metode ini dapat dihandalkan untuk mengatasi ketidaktersedianya data percepatan gempa yang memadai.

Mengacu pada penelitian-penelitian terdahulu, maka dirancanglah penelitian potensi likuifaksi yang berkaitan dengan percepatan maksimum pada kondisi kritis $(F S=1)$. Besarnya nilainya percepatan maksimum kritis yang diperoleh dari analisis balik, diperhitungkan sebagai percepatan maksimum yang terjadi secara linear di seluruh lapisan. Dengan adanya perhitungan analisis ini, maka besaran faktor aman terhadap likuifaksi (FS) dapat diperoleh untuk kondisi percepatan maksimum minimal yang berpotensi memicu likuifaksi di wilayah Kelurahan Lempuing.

Penelitian ini diharapkan dapat menjadi pelengkap bagi penelitian-penelitian terdahulu, serta menjadi pijakan untuk meneliti lebih lanjut potensi likuifaksi di Kelurahan Lempuing, Kota Bengkulu di masa yang akan datang.

\section{Studi Pustaka}

Likuifaksi adalah suatu fenomena kehilangan kekuatan geser tanah pada lapisan jenuh air akibat gempa bumi, sehingga tanah mengalami keruntuhan dan berperilaku seperti cairan (liquid). Likuifaksi umumnya terjadi pada tanah non kohesif (granuler) jenuh air dan menerima beban siklik berupa gempa (Kramer, 1996).

Dewasa ini, metode analisis potensi likuifaksi dengan menggunakan data sekunder penyelidikan tanah telah banyak dikembangkan. Salah satu metode analisis empiris potensi likuifaksi adalah dengan konsep keseimbangan gaya penahan dan gaya pemicu terjadinya likuifaksi, yang dikenal sebagai simplified procedure method. 
Pada dasarnya metode simplified procedure ini merupakan metode keseimbangan batas antara CSR (Cyclic Stress Ratio) and CRR (Cyclic Resistance Ratio), yang bekerja pada tanah saat beban dinamik bekerja pada suatu masa tanah. CSR adalah rasio tegangan siklik yang dihasilkan oleh beban dinamik berupa gempa, sedangankan $C R R$ adalah rasio penahan beban siklik.

Seed dan Idriss (1971) mengusulkan persamaan CSR yang dinyatakan sebagai berikut: $0.65 \frac{\sigma_{v}}{\sigma_{v}^{\prime}} r_{d} \cdot \frac{a_{\max }}{g}$

dengan, $\sigma_{v}$ dan $\sigma_{v}^{\prime}$ masing masing adalah tegangan total dan tegangan efektif tanah, $r_{d}$ adalah faktor reduksi kedalaman yang dinyatakan sebagai $(1-0,012 \mathrm{z}), a_{\max }$ adalah percepatan maksimum gempa (PGA), dan $g$ adalah percepatan gravitasi bumi.

Idriss dan Boulanger (2008) mengusulkan persamaan empiris untuk menghitung $C R R$ dengan menggunakan data CPT. Dibandingkan dengan persamaan-persamaan empiris yang pernah diusulkan oleh Seed dan Idriss (1971), dan Youd dan Idriss (2001), persamaan ini cukup handal dalam perhitungan $C R R$, khususnya bagi penyelidikan tanah yang hanya melakukan uji sondir dalam pekerjaan investigasi lapangan. Nilai $C R R$ berdasarkan Idriss dan Boulanger (2008) dapat diperoleh dengan menggunakan persamaan-persamaan berikut,

$$
C R R=C R R_{M=7}=\left(\begin{array}{l}
\frac{M S F \cdot K_{6}}{\left.\frac{q_{c 1 N c s}}{540}+\left(\frac{q_{c 1 N c s}}{67}\right)^{2}-\left(\frac{q_{c 1 N c s}}{80}\right)^{3} \mathrm{a}\right)} \\
+\left(\frac{q_{c 1 N c s}}{114}\right)^{4}-3
\end{array}\right)
$$

dimana $C R R_{M=7.5}$ adalah ratio ketahanan siklik untuk gempa berskala 7,5, $q_{c l N c s}$ adalah normalisasi tahan konus terhadap tekanan overburden yang diperoleh dari persamaan yang diusulkan oleh Robertson dan Wride (1998), MSF adalahfaktor skala magnitude gempa yang diusulkan oleh Idriss (1999), dan $K_{\text {oadalah faktor tekanan overburden yang }}$ diusulkan oleh Seed (1983).
Berdasarkan persamaan $C S R$ dan $C R R$, maka nilai faktor aman terhadap likuifaksi $(F S)$ dapat dinyatakan sebagai perbandingan antara $C R R$ dan $C S R$, yang dinyatakan sebagai berikut.

$$
F S=\frac{C R R}{C S R}
$$

$\operatorname{dimana} F S \geq 1$, mengindikasikan likuifaksi dapat terjadi, dan $F S<1$, mengindikasikan likuifaksi tidak berpotensi terjadi

Dalam analisis potensi likuifaksi, faktor aman terhadap likuifaksi biasanya diperkuat dengan adanya adanya analisis probabilitas atau kemungkinan terjadinya likuifaksi. Analisis probabilitas likuifaksi bertujuan untuk mengetahui besarnya kemungkinan terjadinya likuifaksi pada suatu nilai $F S$. Selain itu, analisis probabilitas likifaksi juga berperan untuk memberikan informasi, besarnya probabilitas likuifaksi dalam kondisi kondisi kritis $(F S=1)$. Beberapa pendekatan empiris untuk memperkirakan besarnya nilai probabilitas likuifaksi telah banyak diusulkan oleh para ahli. Salah satu persamaan empiris probabilitas likuifaksi yang lazim digunakan adalah persamaan yang diusulkan oleh Juang dkk. (2008), yang dinyatakan dalam persamaan becikut,

$$
1+\left(\frac{F S}{1.05}\right)^{3.8}
$$

dimana, $P L$ adalah probilitas terjadinya likuifaksi.

\section{III.Metodologi}

Penyelidikan tanah dengan menggunakan alat sondir dilakukan di Kelurahan Lempuing, Kota Bengkulu.Lokasi penyelidikan tanah pada penelitian ini diperlihatkan pada Gambar 1.Sebanyak 3 titik penyelidikan dilakukan pada area penelitian.Interpretasi hasil penyelidikan tanah (CPT) dapat dilihat pada Gambar 2.

Secara keseluruhan lapisan tanah di Kelurahan Lempuing didominasi oleh lapisan tanah pasir, dengan kepadatan lepas (loose sand) sampai dengan rapat(dense sand). Pasir dengan kepadatan lepas dijumpai pada kedalaman yang cukup dangkal, pada kedalaman 0 sampai dengan $1 \mathrm{~m}$, dan 8 sampai 
$10 \mathrm{~m}$ dengan rentang nilai $q_{c}$ sebesar 20 sampai dengan $40 \mathrm{~kg} / \mathrm{cm}^{2}$. Pasir dengan kepadatan sedang dijumpai pada kedalaman 1 sampai dengan $6 \mathrm{~m}$, dengan rentang nilai $q_{c}$ sebesar 40 sampai dengan $120 \mathrm{~kg} / \mathrm{cm}^{2}$. Pasir dengan kepadatan rapat dijumpai pada kedalaman 6 sampai dengan $8 \mathrm{~m}$. Rentang nilai $q_{c}$ untuk pasir padat di lokasi penyelidikan berkisar antara 120 sampai dengan $180 \mathrm{~kg} / \mathrm{cm}^{2}$.

Berdasarkan interpretasi penyelidikan tanah, likuifaksi diperkirakan berpotensi terjadi pada lapisan pasir dengan kepadatan lepas sampai dengan lapisan pasir dengan kepadatan sedang. Muka air tanah pada lokasi penyelidikan terletak pada kedalaman $0,5 \mathrm{~m}$ sampai dengan $1 \mathrm{~m}$. Meskipun demikian, dalam analisis ini, muka air tanah diasumsikan berada pada permukaan tanah, sebagai kondisi paling konservatif dalam analisis perhitungan.

Data sondir yang tertera pada Gambar 2, selanjutnya dinormalisasi dengan menggunakan ketentuan yang telah dijelaskan sebelumnya. Dengan menggunakan Persamaan (2) nilai $C R R$ pada masing-masing kedalaman dapat diperoleh. Selanjutnya dengan menggunakan konsep kondisi kritis atau $F S=1$, maka nilai
CSR dapat diperoleh dengan menggunakan Persamaan (3). Analisis balik dengan menggunakan Persamaan (1) selajutnya dilakukan untuk memperoleh besaran nilai percepatan maksimum kritis (PGA kritis). Nilai PGA kritis yang diperoleh selanjutnya dianalisi untuk memperoleh besaran nilai PGA kritis rerata tiap kedalaman. Nilai PGA rerata yang diperoleh selanjutnya digunakan sebagai parameter input dalam perhitungan faktor aman likuifaksi di setiap kedalaman. Dengan diperolehnya faktor keamanan terhadap likuifaksi dalam kondisi kritis, maka interpertasi kerentanan tiap lapisan dapat diperoleh.

Perhitungan probabilitas likuifaksi dilakukan dengan menggunakan Persamaan (4). Dari nilai $F S$ di tiap kedalaman yang diperoleh pada analisis sebelumnya, nilai probabilitas likuifaksi secara keselurahan untuk Kelurahan Lempuing bias diperoleh, dengan mengacu pada hasil penyelidikan tanah yang ditinjau dalam penelitian ini. Interpretasi hasil analisis probabilitas ditampilkan dalam hubungan antara probabilitas likuifaksi $(P L)$ dan faktor aman $(P L)$.

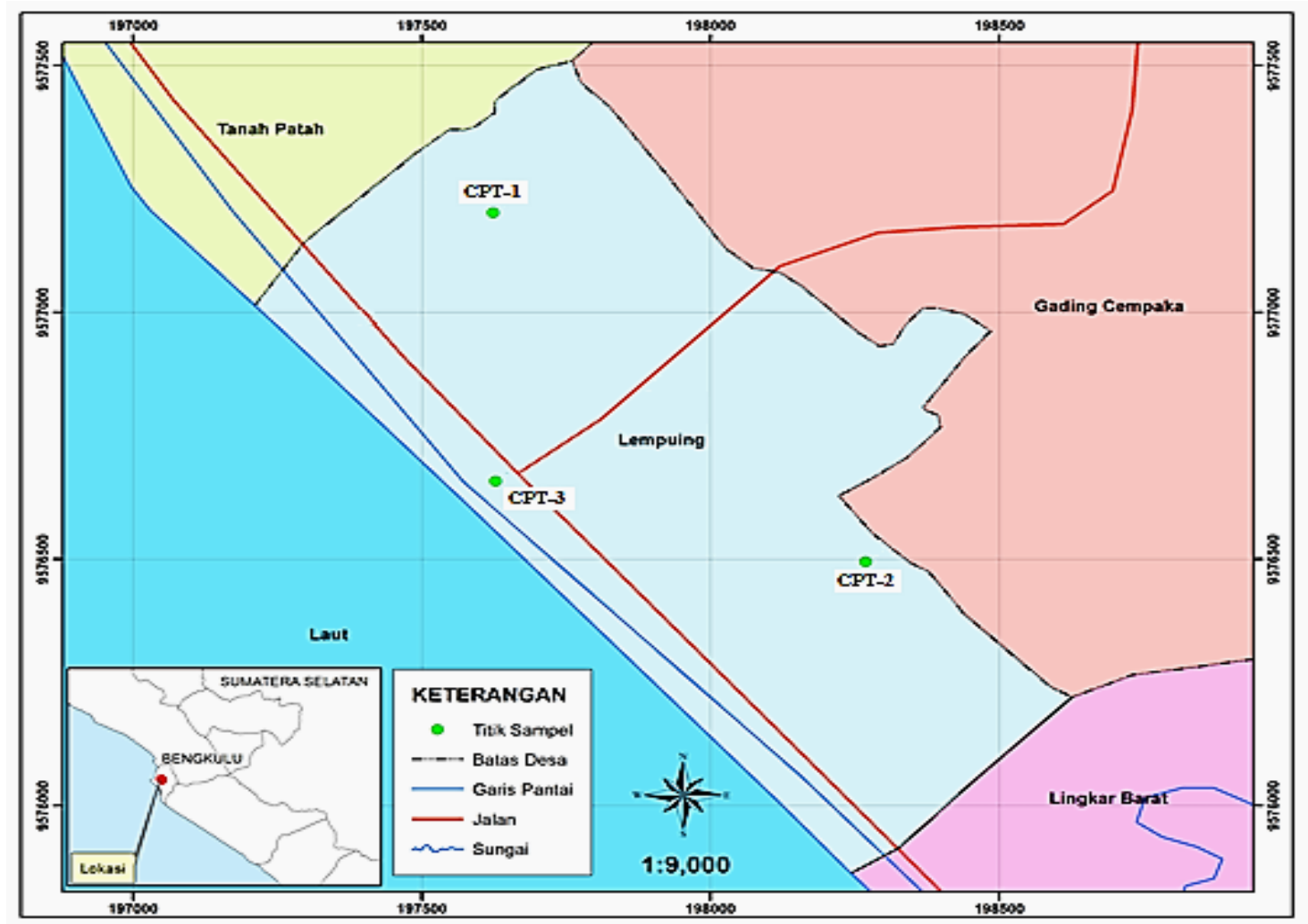

Gambar 1. Layout investigasi penyelidikan tanah (pengujian sondir (CPT)) di Kelurahan Lempuing, Kota Bengkulu 


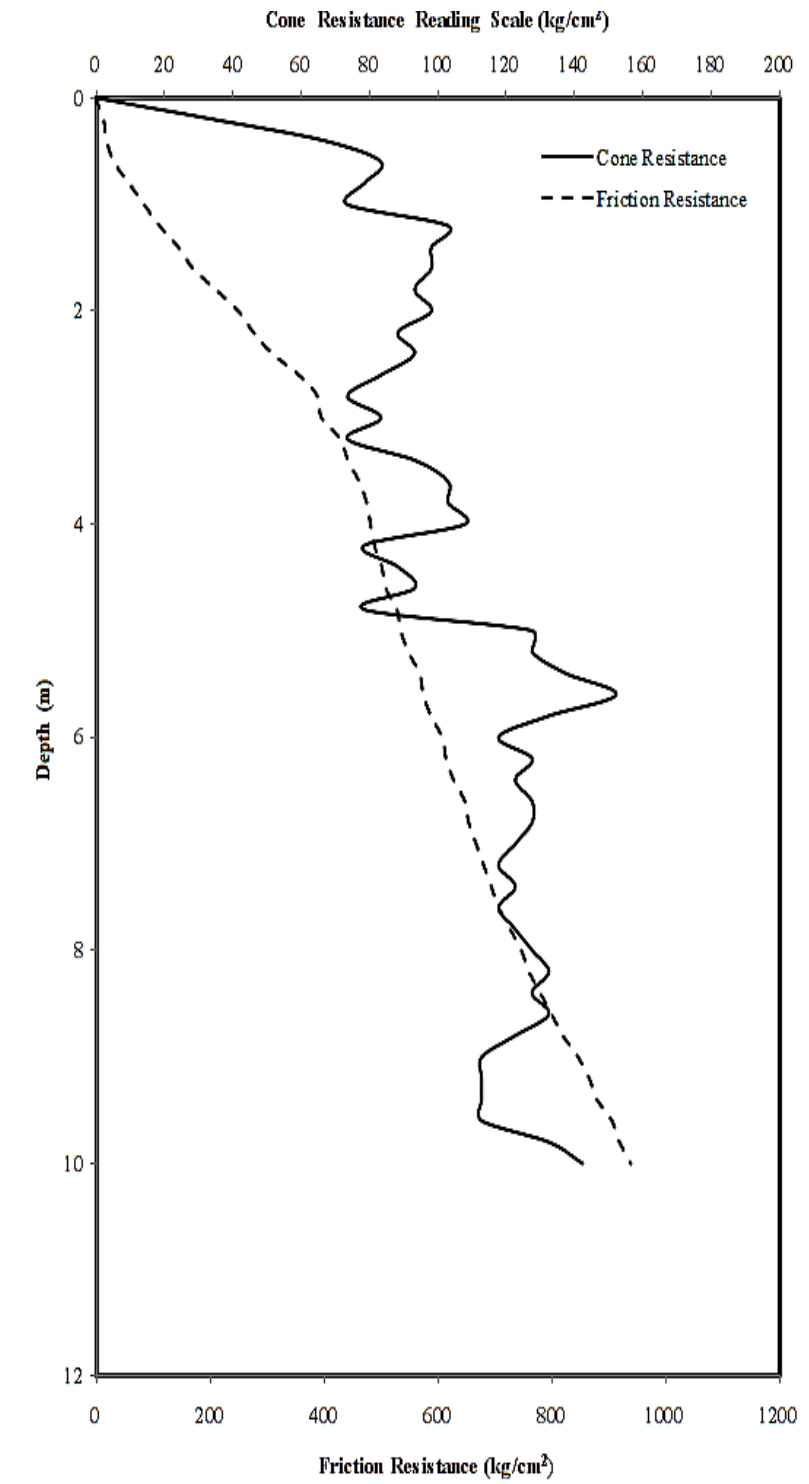

(a)

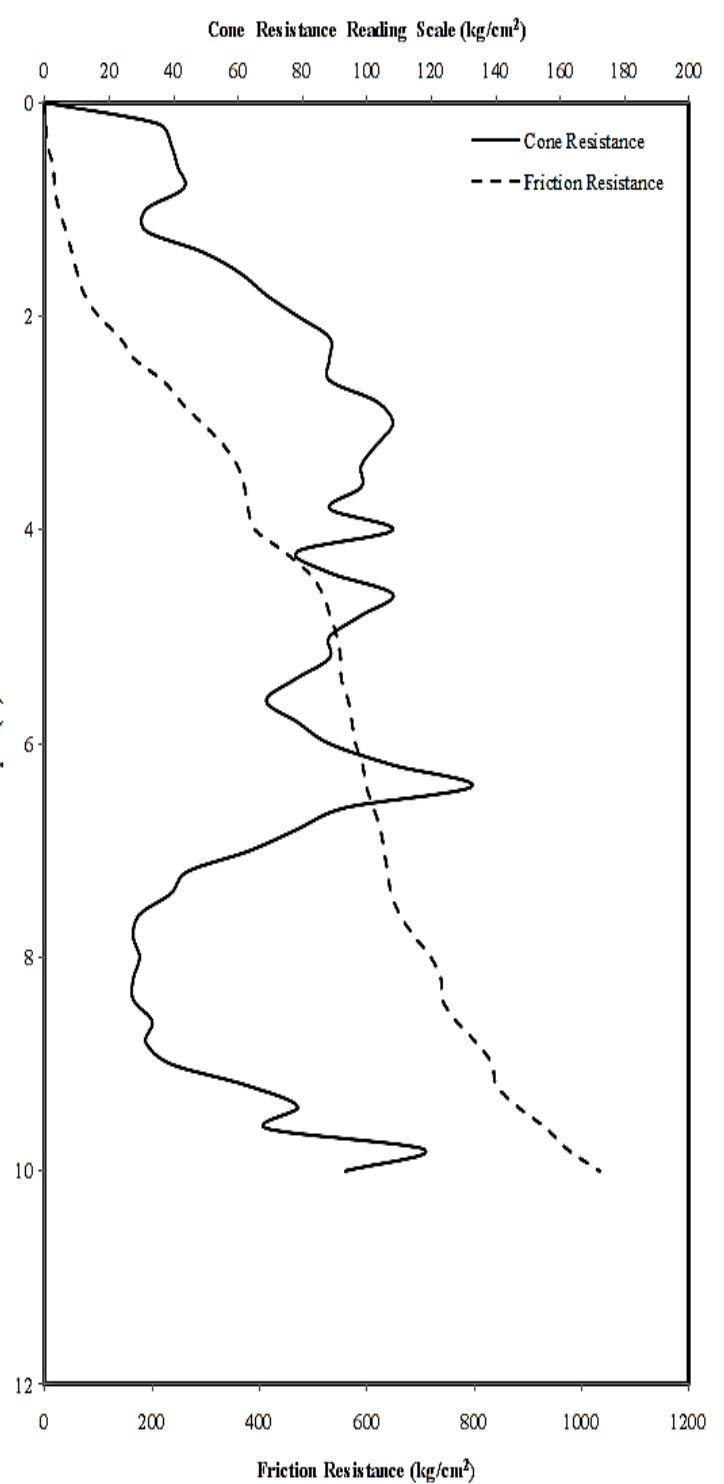

(b)

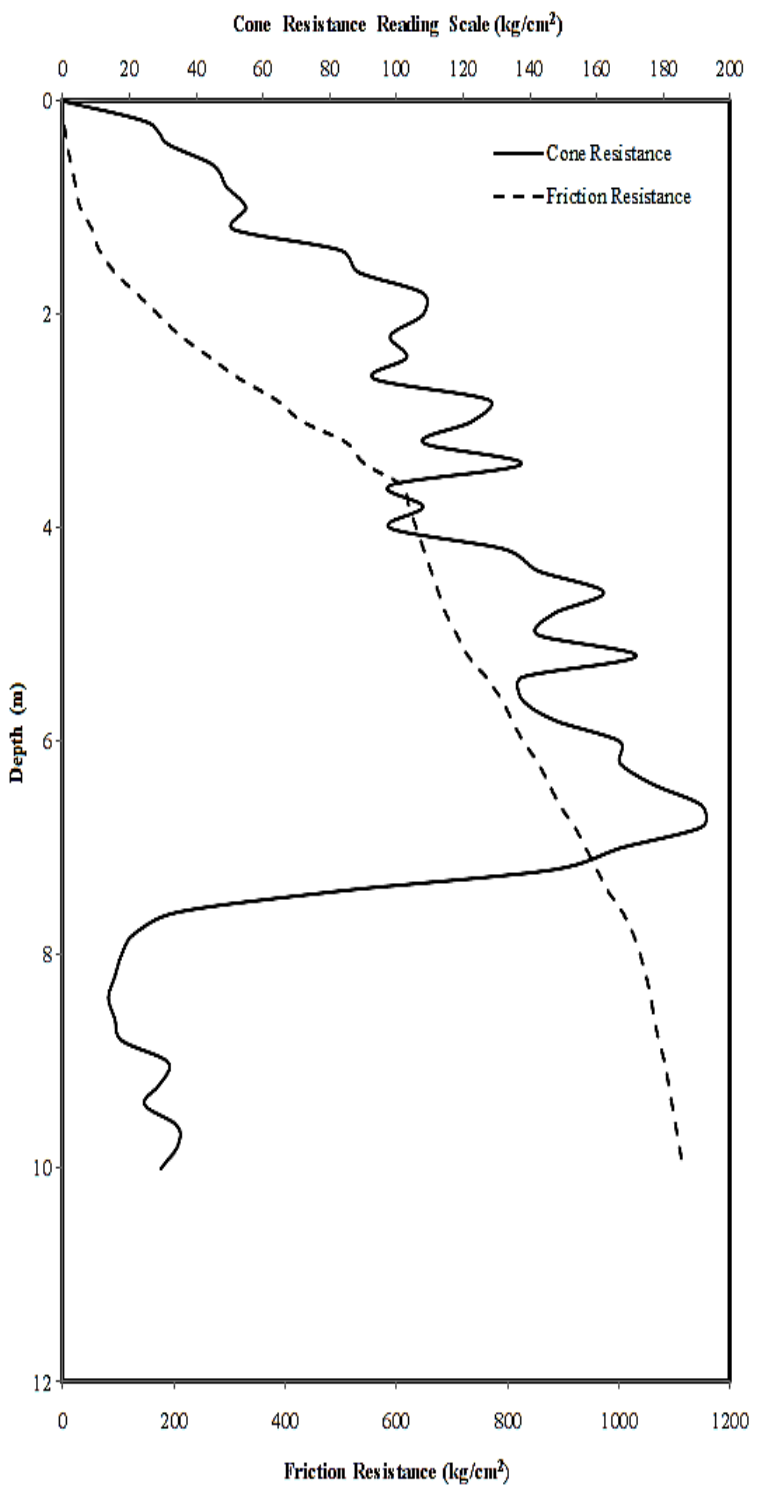

(c)

Gambar 2. Interpretasi hasil penyelidikan tanah menggunakan sondir (CPT) di Kelurahan Lempuing, Kota Bengkulu, (a) CPT-1, (b) CPT-2, dan (c) CPT-3

PUĖnSI Anaisis Potensi Likuifaksi di Kelurahan Lempuing Kota Bengkulu Menggunakan Percepatan Maksimum Kritis 49 Lindung Zalbuin Mase dan Andri Krisnandi Somatri 


\section{Hasil dan Pembahasan}

Interpretasi hasil analisis PGA kritis potensi likuifaksi diperlihatkan pada Gambar 3. Gambar 3a adalah interpretasi PGA kritis dari analisis balik yang untuk titik penyelidikan 1 (CPT-1). Pada Gambar 3a, terlihat bahwa nilai percepatan kritis (PGA kritis) yang dihasilkan oleh Gempa 12 September 2007 pada kedalaman sampai dengan 5,5 m adalah sebesar $0,04 \mathrm{~g}$ sampai dengan $0,07 \mathrm{~g}$. Pada kedalaman $5.5 \mathrm{~m}$ sampai dengan $10 \mathrm{~m}$, PGA kritis semakin meningkat hingga mencapai 0,21g. Dengan bertambahnya nilai PGA kritis dapat disimpulkan bahwa energi gempa yang diperlukan mejadi semakin besar. Hal ini mengindikasikan bahwa tahanan tanah menjadi semakin besar pada titik CPT-1. Dari jumlah varisasi PGA kritis yang dihasilkan, diperoleh nilai PGA rata-rata sebesar $0,079 \mathrm{~g}$.

Interpretasi PGA kritis untuk titik CPT-2, ditunjukkan pada Gambar 3b. Nilai PGA kritis sampai dengan kedalaman $4,5 \mathrm{~m}$ memiliki rentang antara $0,04 \mathrm{~g}$ sampai dengan $0,07 \mathrm{~g}$. Pada kedalaman $4,5 \mathrm{~m}$ sampai dengan $6,8 \mathrm{~m}$, nilai PGA kritis cenderung mengalami peningkatan sampai dengan $0,126 \mathrm{~g}$. Hal ini menunjukkan bahwa ketahan tanah mengalami peningkatan sampai dengan kedalaman tersebut. Pada kedalaman 6,8 m sampai dengan $10 \mathrm{~m}$ nilai PGA kritis cenderug mengalami penurunan. Hal ini mengindikasikan bahwa untuk memicu keadaan kritis pada rentang tersebut, energi gempa bumi yang dibutuhkan relative lebih kecil dibandingkan dengan lapisan sebelumnya. PGA kritis pada rentang kedalaman ini mengalami penurunan sampai dengan $0,075 \mathrm{~g}$. Pada titik CPT-2 nilai PGA rerata yang diperoleh dari PGA kritis adalah $0,065 \mathrm{~g}$.

Interpretasi PGA kritis pada titik CPT-3 dapat dilihat pada Gambar 3c. Pada Gambar tersebut terlihat bahwa sampai dengan kedalaman $5,8 \mathrm{~m}$, bernilai pada rentang $0,04 \mathrm{~g}$ sampai dengan 0,06g. Pada kedalaman 5,8 m sampai dengan $10 \mathrm{~m}$, nilai PGA kritis mengalami peningkatan sampai dengan $0,153 \mathrm{~g}$. Hal ini mengindikasikan bahwa ketahanan tanah yang semakin tinggi, membutuhkan eneri pemicu yang lebih besar dari sebelumnya. Nilai PGA kritis rata-rata pada titik CPT-3 adalah sebesar $0,063 \mathrm{~g}$.

Secara keseluruhan, rentang PGA kritis yang diperlukan untuk keadaan $F S=1$ di Kelurahan Lempuing Bengkulu adalah sebesar
$0,04 \mathrm{~g}-0,21 \mathrm{~g}$. Nilai PGA rerata dari PGA kritis untuk area ini adalah sebesar $0,069 \mathrm{~g}$.

Interpretasi analisis potensi likuifaksi berdasarkan PGA rerata pada masing-masing titik penyelidikan terlihat pada Gambar 4. Gambar 4a merupakan interpretasi hasi analisis pada titik CPT-1. Pada Gambar 4a, terlihat bahwa nilai $F S$ yang dihasilkan sampai dengan kedalaman 5,4 m adalah bernilai kurang dari 1 . Hal ini mengindikasikan bahwa likuifaksi berpotensi terjadi pada rentang kedalaman ini. Pada kedalaman $5.5 \mathrm{~m}$ sampai dengan $10 \mathrm{~m}$, Nilai $F S$ yang dihasilkan bernilai lebih besar dari 1. Hal ini mengindikasikan bahwa lapisan tersebut, cenderung tidak berpotensi mengalami likuifaksi.

Gambar 4b, merupakan interpretasi FS pada titik CPT-2. Berdasarkan hasil analisis, nilai $F S<1$ dihasilkan sampai dengan kedalaman 4,4 $\mathrm{m}$ dan pada rentang 7,5 m sampai dengan 8,5 $\mathrm{m}$ (zona tidak aman). Pada rentang kedalaman 4,4 m sampai dengan 7,5 m dan kedalaman 8,5 m sampai dengan $10 \mathrm{~m}, F S$ yang dihasilkan bernilai lebih besar dari 1 (zona aman).

Gambar 4c merupakan interpetasi $F S$ pada titik CPT-3. Berdasarkan hasil analisis, zona tidak aman berada sampai pada kedalaman 5.8 m. Nilai $F S$ yang dihasilkan adalah bernilai kurang dari 1. Pada rentang kedalaman $5.8 \mathrm{~m}$ sampai dengan $10 \mathrm{~m}$, nilai $F S$ yang dihasilkan bernilai lebih dari 1 . Hal ini mengindikasikan bahwa likuifaksi tidak berpotensi terjadi pada rentang kedalaman tersebut.

Secara keseluruhan nilai $F S$ yang dihasilkan memiliki rentang 0.503 sampai dengan 2.67, dengan kedalaman likuifaksi ratarata terjadi pada kedalaman yang relative dangkal.

Hasil analisis probabilitas likuifaksi untuk area Lempuing tertera pada Gambar 5. Pada Gambar tersebut terlihat bahwa nilai probabilitas likuifaksi mengalami peningkatan seiring dengan menurunnya nilai faktor aman $F S$. Hal ini mengindikasikan bahwa likuifaksi sangat berpotensi terjadi dengan kondisi nilai FS yang bernilai kecil. Probabilitas tertinggi terjadinya likuifaksi pada area penelitian adalah sebesar 0.94 (94\%), yaitu pada kondisi faktor aman bernilai 0.503 . Nilai probabilitas terendah yang dihasilkan adalah bernilai 0.029 (2.9\%), yaitu pada kondisi faktor aman sebesar 2.64. Untuk kondisi kritis atau $F S=1$, nilai probabilitas likuifaksi yang dihasilkan adalah sebesar $0.54(54 \%)$.

PUEE⿰II Anaisis Potensi Likuifaksi di Kelurahan Lempuing Kota Bengkulu Menggunakan Percepatan Maksimum Kritis 50

Lindung Zalbuin Mase dan Andri Krisnandi Somantri 


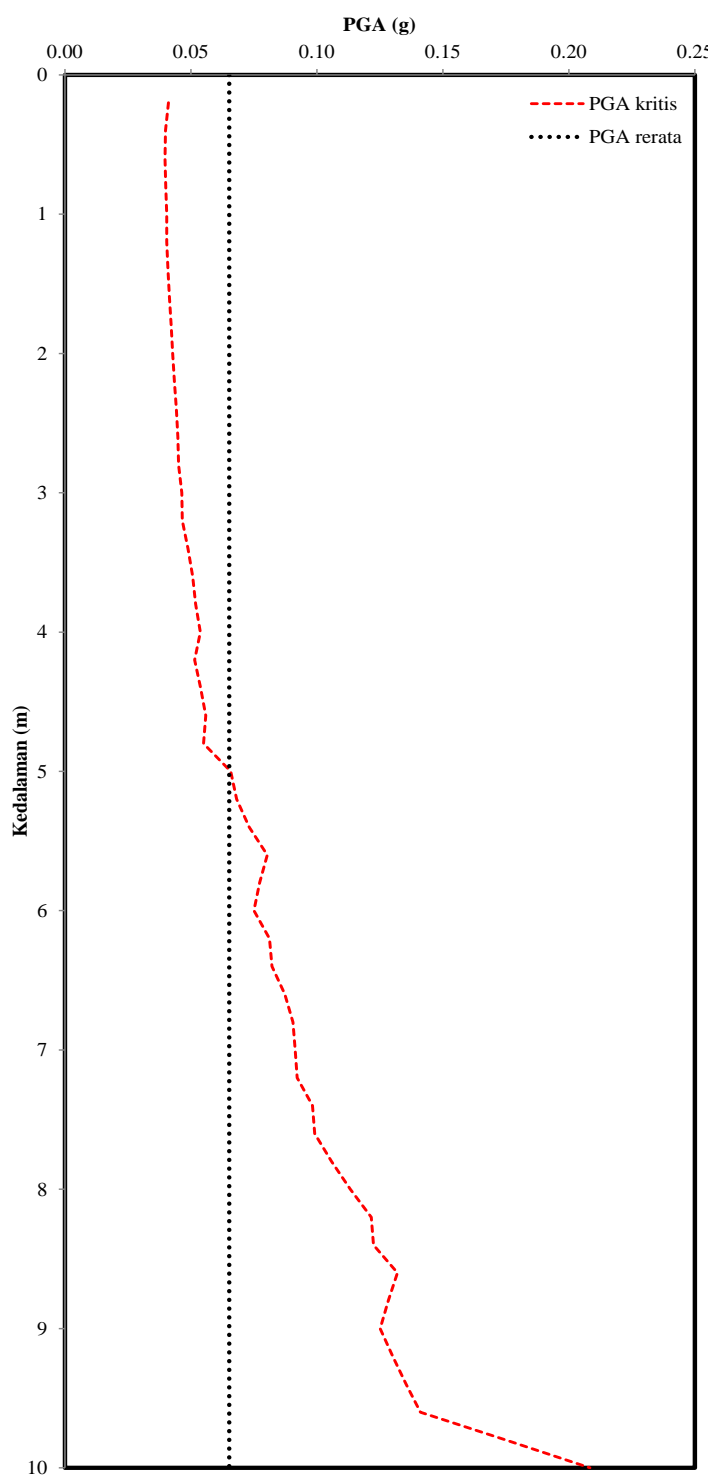

(a)

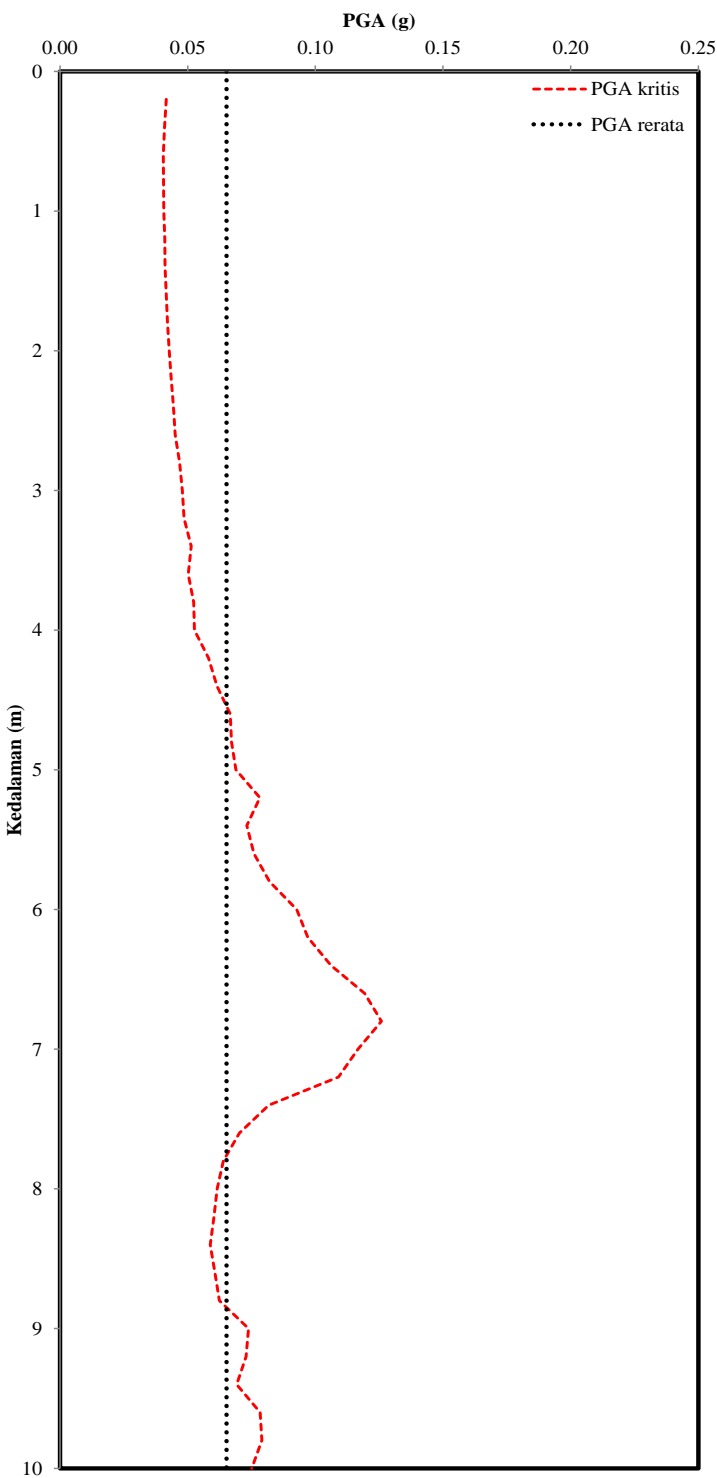

(b)

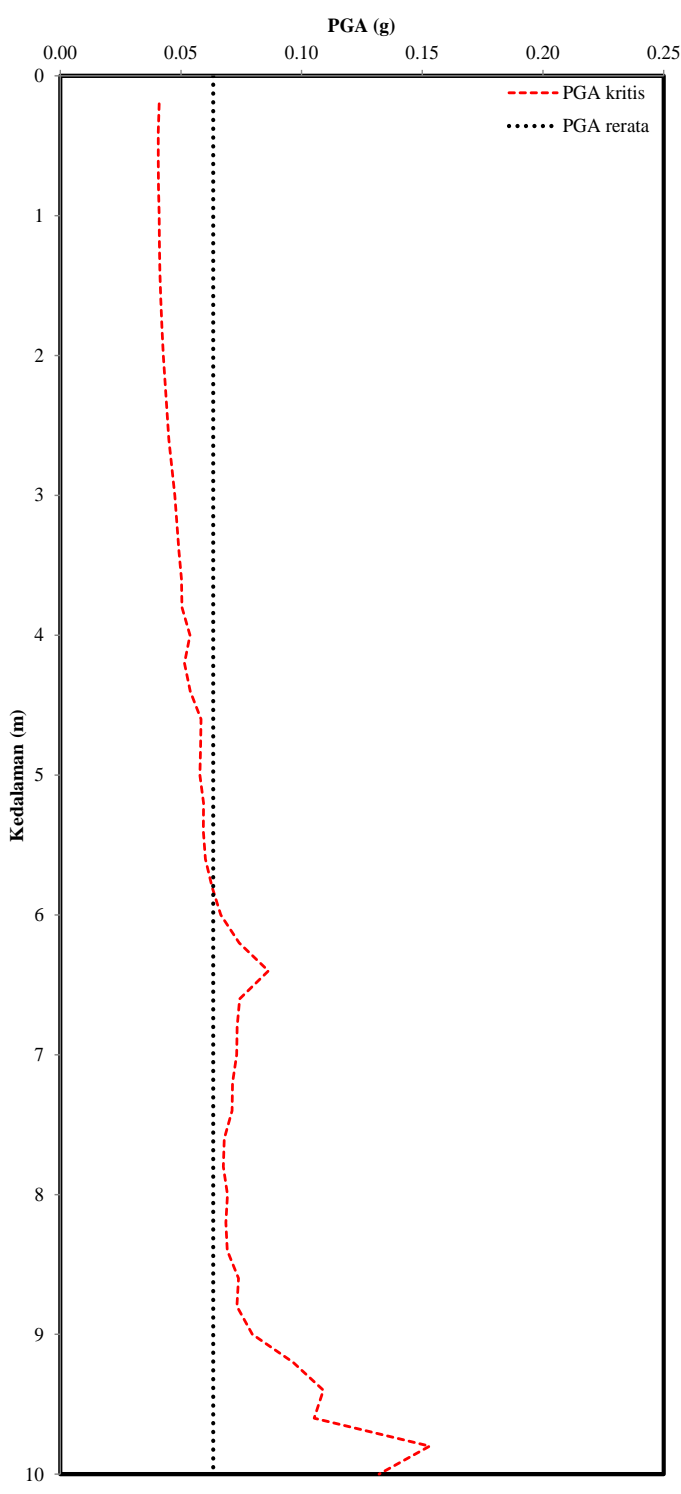

(c)

Gambar 3. Interpretasi PGA kritis dan PGA rerataakibat Gempa 12 September 2007 di Kelurahan Lempuing, Kota Bengkulu, (a) CPT-1, (b) CPT-2, dan (c) CPT-3

PUEEI Anaisis Potensi Likuifaksi di Kelurahan Lempuing Kota Bengkulu Menggunakan Percepatan Maksimum Kritis 51

Lindung Zalbuin Mase dan Andri Krisnandi Somantri 


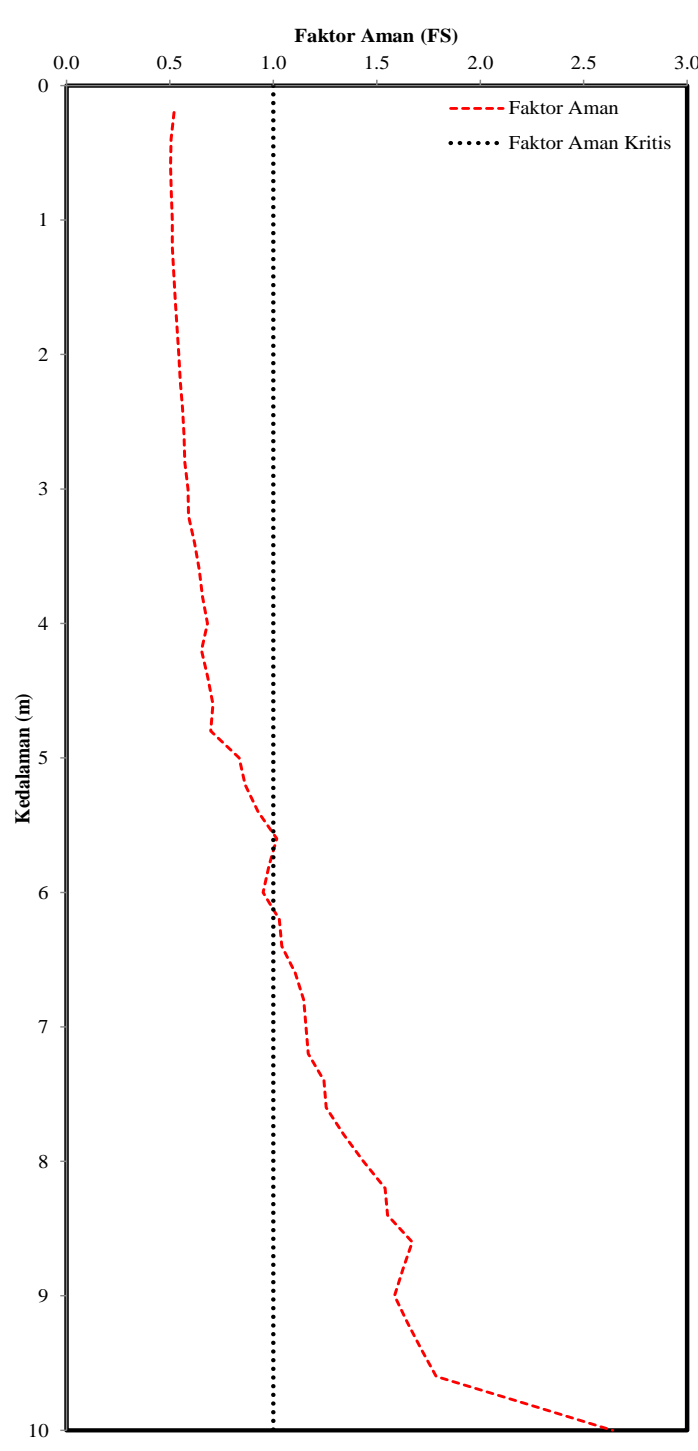

(a)

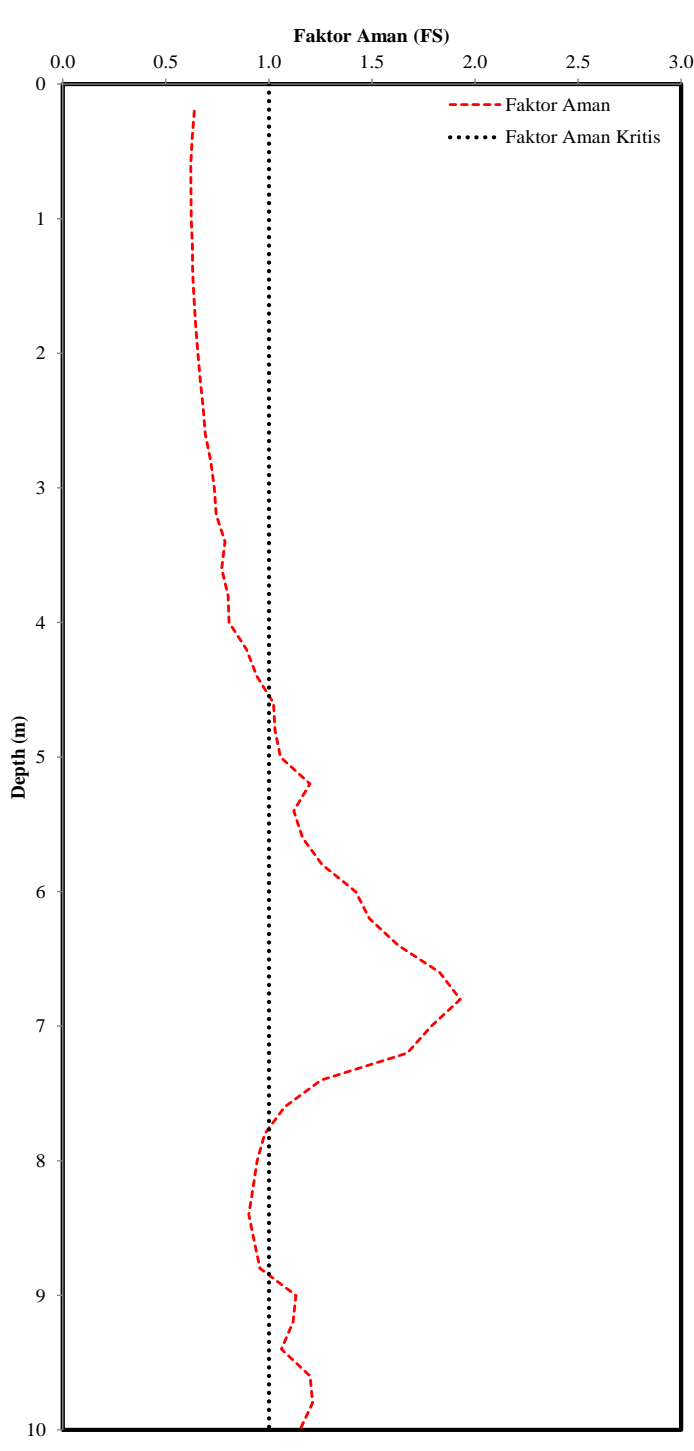

(b)

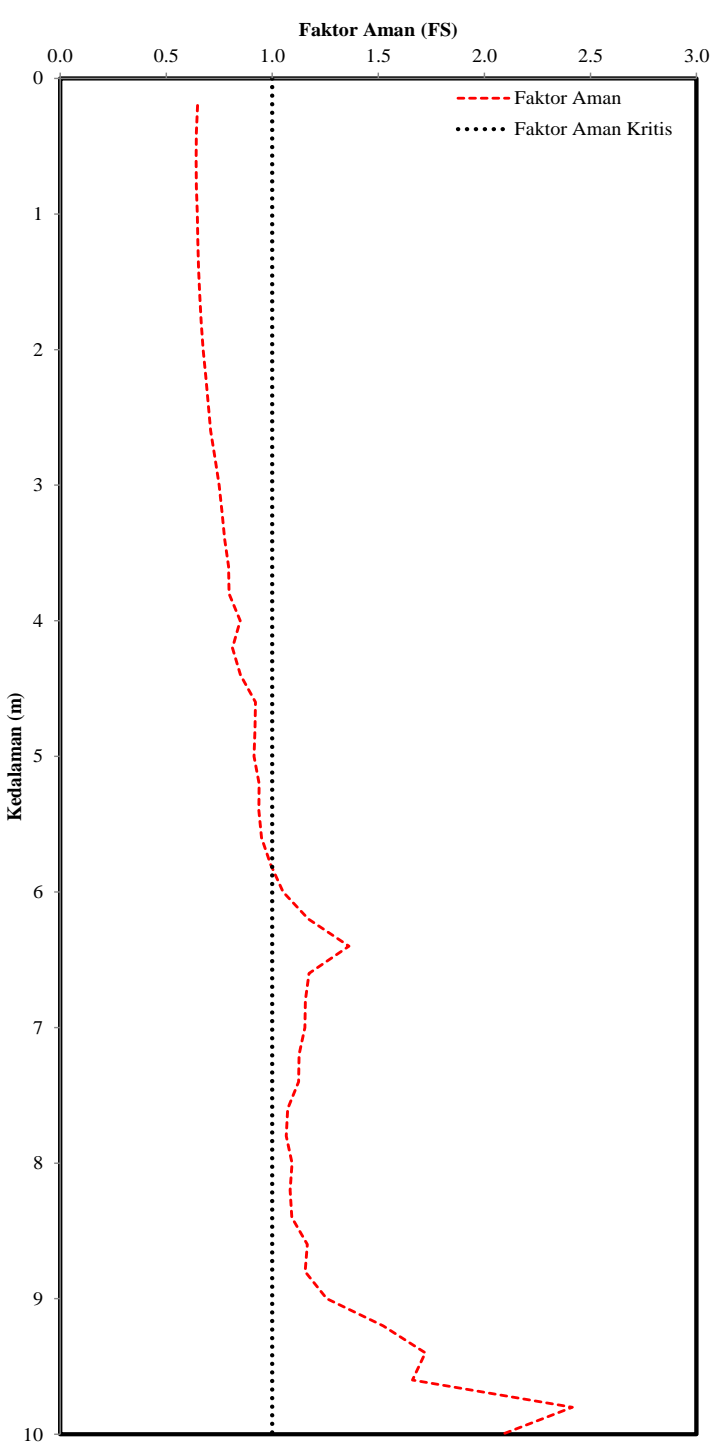

(c)

Gambar 3. Interpretasi FS terhadap likuifaksi Gempa 12 September 2007 di Kelurahan Lempuing, Kota Bengkulu, (a) CPT-1, (b) CPT-2, dan (c) CPT-3

PUĖnSI Anaisis Potensi Likuifaksi di Kelurahan Lempuing Kota Bengkulu Menggunakan Percepatan Maksimum Kritis 52 Lindung Zalbuin Mase dan Andri Krisnandi Somatri 


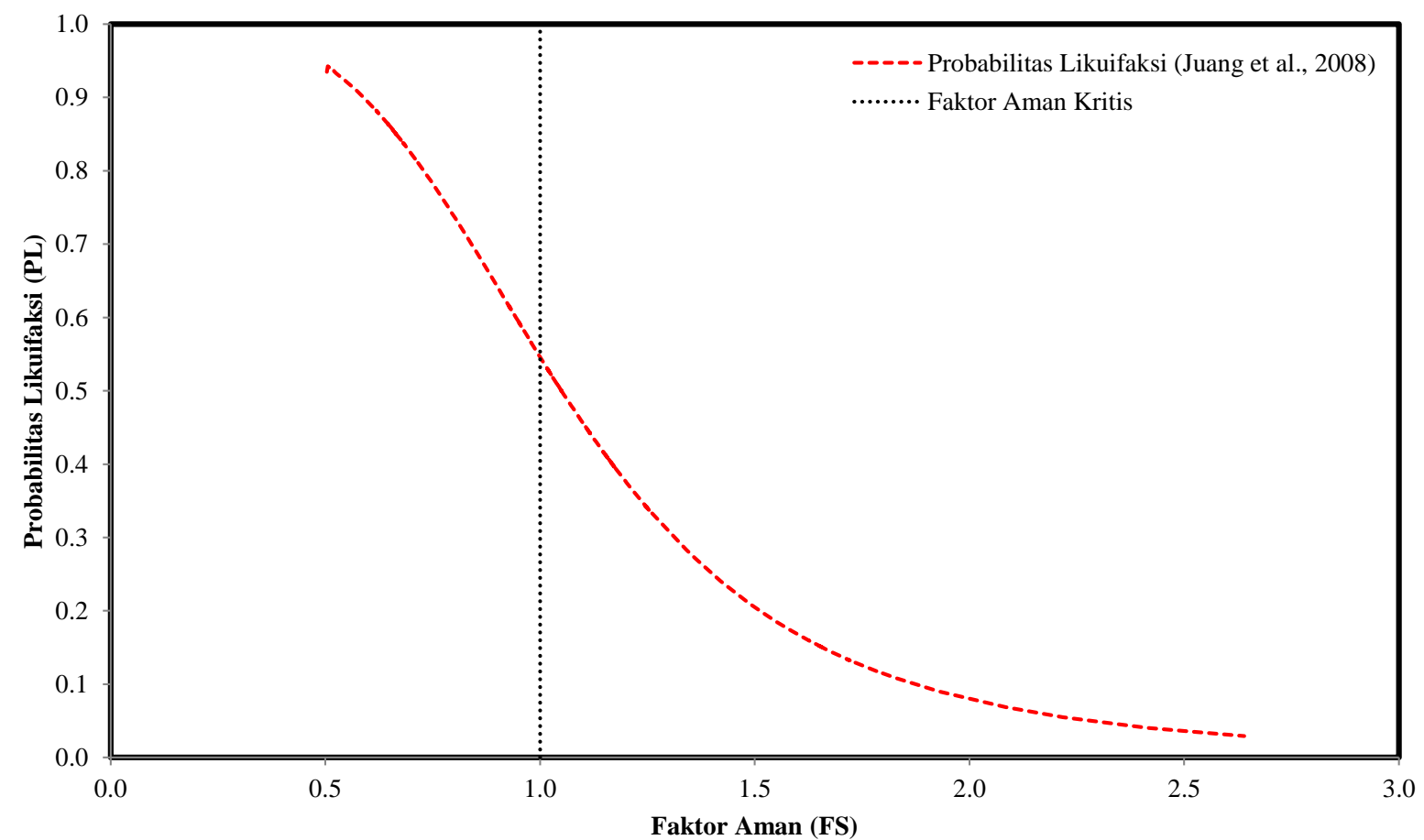

Gambar 5. Interpretasi probabilitas likuifaksi terhadap faktor aman pada analisis potensi likifaksi di Kelurahan Lempuing, Kota Bengkulu.

\section{Kesimpulan}

Penelitian yang mengangkat topik mengenai analisis potensi likuifaksi dengan menggunakan PGA kritis dilakukan sebagai upaya untuk mempelajari potensi likuifaksi di Kelurahan Lempuing, Kota Bengkulu, yang pada 12 September 2007 silam diguncang gempa berkekuatan 7,9 SR. Penelitian ini menganalisis PGA yang dihasilkan keadaan kritis yang atau $F S$ bernilai 1, yang kemudian diperoleh rerata nilai PGA kritis yang digunakan pada analisis potensi likuifaksi secara keseluruhan. Penelitian ini juga menganalisis besarnya kemungkinan terjadinya likuifaksi pada daerah Lempuing, dalam kaitannya dengan nilai $F S$ yang dihasilkan. Beberapa poin yang menjadi kesimpulan dari penelitian ini adalah sebagai berikut :

1. Analisis potensi likuifaksi menggunakan PGA kritis, sangat bermanfaat dalam memprediksi nilai PGA terendah yang berpotensi memicu likuifaksi pada suatu wilayah yang tidak memiliki data rekaman gempa yang cukup memadai.

2. Hasil analisis likuifaksi yang diperoleh dari penelitian ini hanya memberikan nilai PGA kritis pada tiap titik kedalaman dan tidak dalam bentuk rentang nilai. Apabila mengacu pada penelitian Muntohar (2009 dan 2014), nilai PGA yang dihasilkan diinterpretasikan dalam bentuk interval keyakinan (confidence interval), sehingga nilai rentang PGA kritis yang dapat diterima, dapat diketahui. Dengan mengacu pada penelitian Muntohar (2009 dan 2014), penelitian ini selanjutnya akan dikembangkan dengan memperkirakan rentang PGA kritis pada area penelitian ini.

3. Nilai faktor aman yang diperoleh dari hasil penelitian ini memberikan gambaran bahwa nilai PGA kritis mampu memicu likuifaksi pada kedalaaman yang cukup dangkal. Nilai $q_{c}$ berkisar antara 20 sampai dengan $100 \mathrm{~kg} / \mathrm{cm}^{2}$, hendaknya menjadi perhatian dalam perencanaan fondasi di Kelurahan Lempuing. Rentang nilai $q_{c}$ tersebut merupakan pasir dengan kategori rendah sampai sedang. Meskipun demikian, letak muka air tanah yang cukup rendah berpotensi menjadi pemicu lain dalam mengganggu stabilitas ketahanan tanah saat gempa terjadi. Selain itu, estimasi penurunan tanah juga perlu dilakukan, dengan menggunakan beberapa metode yang pernah diusulkan, salah satunya oleh Zhang et al. (2002). Semua analisis tersebut perlu dilakukan sebagai pertimbangan dalam merancang fondasi bangunan gedung di wilayah Kelurahan Lempuing. 
4. Probabilitas likuifaksi menjadi hal yang penting dalam analisis likuifaksi, meskipun dalam penelitian ini, perhitungan hanya mempertimbangkan nilai $F S$ sebagai variabel penentu. Analisis probabilitas dengan mempertimbangkan variabel yang lain sangat penting untuk dilakukan, seperti yang diusulkan oleh Idriss dan Boulanger (2010) dan Cetin dkk. (2004).

5. Dengan dilakukannya penelitian likuifaksi di Kelurahan Lempuing, maka hasil penelitian ini mengkonfirmasi hasil penelitian yang dilakukan oleh Misliniyati dkk. (2013) dan Monalisa dkk. (2014), yang menyatakan bahwa likuifaksi berpotensi terjadi di wilayah Kelurahan Lempuing.

6. Penelitian likuifaksi di Kelurahan Lempuing, menjadi pijakan awal dalam meneliti potensi likuifaksi di wilayah Kota Bengkulu khususnya dan di Provinsi Bengkulu pada umumnya. Selanjutnya, pengembangan peta kerentanan likuifaksi pada area pesisir Kota Bengkulu dan Provinsi Bengkulu dapat dilakukan.

\section{Ucapan Terima Kasih}

Ucapan terima kasih yang sebesar-besarnya disampaikan kepada Kepala Laboratorium Mekanika Tanah Jurusan Teknik Sipil, Fakultas Teknik, Universitas Bengkulu beserta staf, atas bantuan dalam melakukan survei lapangan dan penyelidikan tanah di Kelurahan Lempuing Kota Bengkulu. Penulis juga mengucapkan terima kasih yang sebesar-besarnya kepada semua pihak yang telah ikut membantu dalam penelitian ini

\section{Daftar Pustaka}

Cetin, K. O., Seed, R. B., Der Kiureghian, A., Tokimatsu, K., Harder,L. F., Kayen, R. E., and Moss, R. E. S., 2004. Standard Penetration Test-Based Probabilistic And Deterministic Assessment Of Seismic Soil Liquefaction Potential, J. Geotechnical and Geoenvironmental Eng., ASCE 130(12), 1314-340

Haldar, A, and Tang, H.W., (1979), Probabilistic Evaluation of Liquefaction Potential, Journal of Geotechnical Engineering, ASCE Vol. 105, No.GT2. pp 145-153.
Idriss, I. M., 1999. An update to the Seed-Idriss simplified proce-dure for evaluating liquefaction potential, in Proceedings, TRB Workshop on New Approaches to Liquefaction, Publication No.FHWA-RD99-165, Federal Highway Administration, January

Idriss, I.M., and R. W. Boulanger [2008], Soil liquefaction during earthquakes, Monograph MNO-12, Earthquake Engineering Research Institute, Oakland, CA, $261 \mathrm{pp}$.

Idriss, I.M., Boulanger, R.W., 2010. "SPT-Based Liquefaction Triggering Procedures. Report No. UCD/CGM-10/02. Center for Geotechnical Modeling", Department of Civil and Environmental Engineering, University of California at Davis.

Juang, C. H., Fang, S. Y., Li, D. L. (2008). Reliability Analysis of Liquefaction Potential Of Soils Using Standard Penetration Test. Edited by Phoon, K. K, in Reliability-Based Design in Geotechnical Engineering.

Kramer, S.L., 1996, Geotechnical Earthquake Engineering, Prentice Hall, Englewood Cliffs, N. J., 653.

Misliniyati, R., Mawardi, Besperi, Razali, M.R., Muktadir, 2013, Pemetaan Potensi Likuifaksi Wilayah Pesisir Berdasarkan Data Cone Penetration Test di Kelurahan Lempuing, Kota Bengkulu, Journal of Inersia: Volume 5. No.2, October, 2013, ISSN : 2086-9045.

Monalisa A., Misliniyati, R., and Gunawan, A., 2014, "Analysis of Liquefaction Potential Using Simple Probability Method Based on CPT Data in Lempuing Sub-District", Bengkulu City", Undergraduate Final Project :Department of Civil Engineering, Faculty of Engineering, Universitas Bengkulu : Bengkulu.

Muntohar, A.S, 2009, Evaluation of Peak Ground Acceleration Using CPT Data for Liquefaction Potential, The $4^{\text {th }}$ Annual International Workshop and Expo on Sumatra Tsunami Disaster and Recovery

Muntohar, A.S., 2014, Research on Earthquake Induced Liquefaction in Padang City and Yogyakarta Area, Jurnal Geoteknik HATTI IX (1), ISSN 0853-4810.

Robertson, P. K., and Wride, C. E., 1998. Evaluating cyclic liq-uefaction potential using the cone penetration test, CanadianGeotechnical J. 35(3), 442-59.

Seed, H. B., 1983. Earthquake resistant design of earth dams, inProceedings, Symposium on Seismic Design of Embankments andCaverns, Pennsylvania, ASCE, NY, pp. $41-64$ 
Seed, H.B., and Idriss, I.M., 1971, Simplified Procedure for Evaluation Soil Liquifaction Potential, Journal of Soil Mechanics and Foundation, Division, ASCE, vol. 97, No.9, pp 1249-1273.

SNI 03-1726-2010, 2010, Standar Perencanaan Ketahanan Gempa Untuk Struktur Bangunan Gedung, Departemen Pekerjaan Umum.

Youd, T. L., and Idriss, I.M. (2001) "Liquefaction resistance of soils: Summary report from the 1996 NCEER and 1998 NCEER/NSF workshops on evaluation of liquefaction resistance of soils." J. Geotech. Geoenviron. Eng., ASCE, 127(10), 817833.

Zhang, G., P. K.,Robertson, and R. W. I. Brachman, 2002. Estimating Liquefaction-Induced Ground Settlements From CPT For Level Ground, Canadian Geot. J., Ottawa, 39: $1168-1180$ 